\title{
In vitro antiviral activity of antimicrobial peptides against herpes simplex virus 1 , adenovirus, and rotavirus
}

\author{
Márcia Cristina Carriel-Gomes, Jadel Müller Kratz, Margherita Anna Barracco*, Evelyne

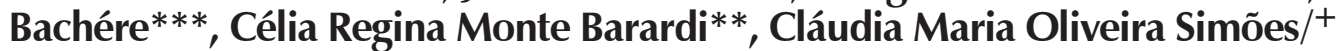

\begin{abstract}
Laboratório de Virologia Aplicada, Departamento de Ciências Farmacêuticas *Laboratório de Imunologia Aplicada à Aqüicultura, Departamento de Biologia Celular, Embriologia e Genética **Laboratório de Virologia Aplicada, Departamento de Microbiologia e Parasitologia, Universidade Federal de Santa Catarina, Campus Trindade, 88040-900 Florianópolis, SC, Brasil ***CNRS-Université de Montpellier II, Ifremer, Montpellier, France
\end{abstract}

Peptides with broad-spectrum antimicrobial activity, known as antimicrobial peptides, have been isolated from distinct organisms. This paper describes the in vitro evaluation of the cytotoxicity and antiviral activity of nine peptides with different structures and origins against herpes simplex virus type 1, human adenovirus respiratory strain, and rotavirus SA11. Most of the evaluated peptides presented antiviral activity but they were only active near cytotoxic concentrations. Nevertheless, these results seem promising, and further modifications on the peptide's structures may improve their selectivity and reduce their cytotoxicity.

Key words: antimicrobial peptides - antiviral activity - herpesvirus - adenovirus - rotavirus

Many peptides with broad-spectrum antimicrobial activity, typically known as antimicrobial peptides (AMPs), have been isolated from a wide panel of organisms, including mammals, amphibians, molluscs, tunicates, and arthropods (Bachère et al. 2000, Yasin et al. 2000, van der Strate et al. 2001, Zasloff 2002, Bulet et al. 2004, Chinchar et al. 2004, Park \& Hahm 2005).

Most of them are cationic, amphipathic molecules that contain 15 to 40 amino acid residues, which can be loosely grouped into three major groups: $\alpha$-helical peptides (e.g., magainins), cyclic and open-ended cyclic peptides with pairs of cysteine residues (e.g., defensins), and peptides with an over-representation of some amino acids (e.g., proline rich) (Yasin et al. 2000, Zasloff 2002, Bulet et al. 2004).

Although the antibacterial and antifungal activities of AMPs have been the main focus of the studies to date, some of these molecules have also been shown to be effective against viral pathogens (Yasin et al. 2000, van der Strate et al. 2001, Oevermann et al. 2003, Matanic \& Castilla 2004, Sun et al. 2005). For instance, lactoferrin, a glycoprotein present in the milk, inhibited the human immunodeficiency virus (HIV-1), herpes simplex virus types 1 (HSV-1) and 2 (HSV-2), human cytomegalovirus, respiratory syncytial virus, hepatitis $\mathrm{B}$ and $\mathrm{C}$ virus, adenovirus, and rotavirus (van der Strate et al. 2001,

Financial support: CNPq (grant 47.2337/2003-3), European Community (INCO-DEV IMMUNAQUA Project Contract ICA4CT-2001-10023)

${ }^{+}$Corresponding author: claudias@ reitoria.ufsc.br

MAB, CRMB, CMOS are CNPq fellowship

JMK is Capes fellowship

Received 18 October 2006

Accepted 7 March 2007
Orsi 2004) in vitro, highlighting the importance of naturally occurring proteic molecules as antiviral agents.

This report describes the evaluation of the antiviral activity of nine antimicrobial peptides with different structures against HSV-1, human adenovirus respiratory strain (AdV-5), and rotavirus SA11 (RV-SA11), viruses that represent a challenge to the public health system due to their limiting symptomatic treatment.

\section{MATERIALS AND METHODS}

Antimicrobial peptides - The peptides used in this study are described in Table I. PW-2 and Gomesin were kindly donated by Dr Arnaldo Silva Junior (Unicamp, Campinas, SP) and by Dr Sirley Daffre (ICB-USP, SP, Brazil), respectively. The further evaluated peptides were extracted from the respective sources described in Table I. Stock solutions were prepared in sterile MilliQ® water at $1 \mu \mathrm{M}$ and stored at $-20^{\circ} \mathrm{C}$ until use.

Cell culture and viruses - Vero (ATTC CCL-81), HEp-2 (ATCC CCL-23), and MA104 cells (ATTC CRL2378.1) were grown and maintained in minimum essential medium (MEM, Sigma) supplemented with $10 \%$ fetal bovine serum (FBS, Gibco BRL) and $1 \%$ of antibiotics PSA (100 IU/ml penicillin G, $100 \mu \mathrm{g} / \mathrm{ml}$ streptomycin and $0.025 \mathrm{mg} / \mathrm{ml}$ amphotericin B; Gibco BRL) at $37^{\circ} \mathrm{C}$ in a humidified $5 \% \mathrm{CO}_{2}$ atmosphere. HSV-1, KOS strain (Laboratory of Pharmacognosy, Faculty of Pharmacy, University of Rennes, France), AdV-5, and RV-SA11 (both from ICB-USP, SP, Brazil) were propagated and titrated in Vero, HEp-2, and MA104 cells, respectively.

Cytotoxicity evaluation - The cell viability was evaluated by the 3-(4,5-dimethylthiazol-2-yl)-2,5-diphenyl tetrazolium bromide (MTT) method (Mossmann 1983, Sieuwerts et al. 1995), with minor modifications. Vero, HEp-2, and MA104 cells were grown in 96-well plates for $24 \mathrm{~h}$ at $37^{\circ} \mathrm{C}$ in a humidified $5 \% \mathrm{CO}_{2}$ atmosphere. Following incubation, media was replaced with fresh MEM containing two-fold serial dilutions of the pep- 
TABLE I

Characteristics of peptides used in this study

\begin{tabular}{llll}
\hline Peptides & Reference & Source & Amino acid sequence \\
\hline PW-2 & da Silva Jr et al. 2001 & Recombinant & HPLKQYWWRPSI \\
Tachyplesin-1 & Murakami et al. 1991 & Limulid & KWCFRVCYRGICYRRCR ${ }^{a}$ \\
Gomesin & Mandard et al. 2002 & Spider & ZCRRLCYKQRCVTYCRGR $^{a}$ \\
Clavanin A & Lee et al. 1997 & Tunicate & VFQFLGKIIHHVGNFVHGFSHVF $^{a}$ \\
Magainin $^{b}$ & Zasloff 1987 & Frog & GIGKFLKKAKKFGKAFVKIMKK $^{a}$ \\
$\mathrm{HCTF}^{c}$ & Destoumieux-Garzon et al. 2001 & Synthetic & FEDLPNFGHHIQLKVFNHGEHIHH
\end{tabular}

$\begin{array}{lll}\text { Penaeidin-3 }^{d} & \text { Yang et al. } 2003 & \text { Shrimp }\end{array}$

QGA: VYKGGYTRPIPRPPPPVRPL PGGPIGPYNGCFV SCRGISFSQAR SCCSRLGRCCHVGKGYSG pEGA: PEVYKGGYTRPIPRPPPPV RPLPLPGGPIGPYNGCFVSCRGIS FQARSCCSRLGRCCHVGKGYSG

$\mathrm{ALF}^{e} \quad$ Somboonwiwat et al. $2005 \quad$ Shrimp

QGWEAVAAAVASKIVGLWRNEK TELLGHECKFTVKPYLKRFQVY YKGRMWCPGWTAIRGEASTRSQ SGVAGKTAKDFVRKAFQKGLISQ QEANQWLSS

Mytilin A Charlet et al. $1996 \quad$ Mussel

GCASRCKAKCAGRRCKGWASAS FRGRCYCKCFRC

$a$ : C-terminal amidation; $b$ : the magainin used in this work is the synthetic analog MSI-94; $c$ : hemocyanin C-terminal factor; $d$ : the penaeidin-3 used in this work is a mixture (1:1) of two recombinant analogs QGA and pEGA; $e$ : antilipolysaccharide factor.

TABLE II

Cytotoxicity of peptides obtained by 3-(4,5-dimethylthiazol-2-yl)-2,5-diphenyl tetrazolium bromide (MTT) assay

\begin{tabular}{llll}
\hline Peptides & $\mathrm{CC}_{50}{ }^{a}$ Vero & $\mathrm{CC}_{50}$ HEp-2 & $\mathrm{CC}_{50} \mathrm{MA}{ }^{204}$ \\
\hline PW-2 & $>125$ & $84.90 \pm 5.83$ & $>125$ \\
Tachyplesin-1 & $\mathrm{Nt}$ & $\mathrm{Nt}$ & $23.70 \pm 3.96$ \\
Gomesin & $78.30 \pm 11.31$ & $50.63 \pm 1.55$ & $24.30 \pm 2.65$ \\
Clavanin A & $\mathrm{Nt}$ & $25.50 \pm 5.57$ & $50.23 \pm 7.62$ \\
Magainin & $39.72 \pm 0.85$ & $37.15 \pm 5.28$ & $33.52 \pm 2.38$ \\
HCTF & $>80$ & $\mathrm{Nt}$ & $\mathrm{Nt}$ \\
Penaeidin-3 & $>100$ & $42.85 \pm 4.85$ & $21.03 \pm 4.27$ \\
ALF & $47.20 \pm 11.00$ & $17.13 \pm 1.23$ & $35.91 \pm 6.15$ \\
Mytilin A & $49.84 \pm 3.34$ & $\mathrm{Nt}$ & $>80$
\end{tabular}

$\mathrm{CC}_{50}$ : concentration $(\mu \mathrm{M})$ that reduced the absorbance of treated cells by $50 \%$ when compared to cell control. Results are expressed as mean \pm SDM of three separate experiments; Nt: not tested; HCTF: hemocyanin C-terminal factor; ALF: antilipolysaccharide factor.

tides. After 72, 96, and $120 \mathrm{~h}$ of incubation, respectively, for MA104, Vero, and HEp-2 cells at the same conditions mentioned above, the cytotoxicity was assessed and expressed as $\mathrm{CC}_{50}$ (concentration that reduced the absorbance of treated cells by $50 \%$ when compared to control - untreated cells). All assays were performed in triplicate.

Antiviral assays - The antiviral assays were based upon cell viability also using the MTT method as reported by Takeuchi et al. (1991) in their studies with HSV. The technical details are described below, depending on the used strategy. For the simultaneous assay, Vero, HEp-2, and MA104 cells were grown in 96-well plates for $24 \mathrm{~h}$ at $37^{\circ} \mathrm{C}$ in a humidified $5 \% \mathrm{CO}_{2}$ atmosphere. Following incubation, media was replaced with fresh MEM containing two-fold serial dilutions of non-cytotoxic concentrations (below $\mathrm{CC}_{50}$ values) of the peptides and each one of the evaluated viruses $(\mathrm{MOI}=0.5)$. Plates were incubated for different periods of time according to each virus: $72 \mathrm{~h}$ for RV-SA11, $96 \mathrm{~h}$ for HSV-1, and $120 \mathrm{~h}$ for $\mathrm{AdV}-5$ at the same conditions mentioned above. The percentages of protection were calculated as $[(\mathrm{A}-\mathrm{B}) /(\mathrm{C}-\mathrm{B})$ $\times 100$ ], where $A, B$, and $C$ indicate the absorbance of the peptides, virus and control cells, respectively. The calculated $\mathrm{EC}_{50}$ value was defined as the concentration that reduced the absorbance of infected cells to $50 \%$ when compared to infected cells and control cells. To determine whether the compounds inhibited viruses replication by affecting their adsorption or penetration on the host cells another strategy was adopted, the pretreatment assay (Bettega et al. 2004). Vero, HEp-2, and MA104 cells were grown as described above and following incubation, media was replaced with fresh MEM containing two-fold serial dilutions of non-cytotoxic concentrations of the peptides. Plates were incubated for $3 \mathrm{~h}$ prior to virus infection and further incubation periods. 
TABLE III

Percentages of inhibition of the different tested viruses by peptides, obtained by 3-(4,5-dimethylthiazol-2-yl)-2,5-diphenyl tetrazolium bromide (MTT) assay, using different strategies of evaluation

\begin{tabular}{|c|c|c|c|c|c|c|}
\hline \multirow[b]{2}{*}{ Peptides } & \multicolumn{2}{|c|}{ Herpes simplex virus type 1} & \multicolumn{2}{|c|}{$\begin{array}{l}\text { Human adenovirus } \\
\text { respiratory strain }\end{array}$} & \multicolumn{2}{|c|}{ Rotavirus SA11 } \\
\hline & Conc & $\%$ & Conc. & $\%$ & Conc. & $\%$ \\
\hline $\begin{array}{l}\text { PW-2 } \\
\text { Sim } \\
\text { Pre }\end{array}$ & 125 & $\begin{array}{l}70.91 \pm 2.46 \\
25.08 \pm 9.90\end{array}$ & 80 & $\begin{array}{l}36.67 \pm 6.61 \\
24.60 \pm 5.70\end{array}$ & 125 & $\begin{array}{l}18.66 \pm 4.67 \\
31.69 \pm 14.09\end{array}$ \\
\hline $\begin{array}{l}\text { Tachyplesin-1 } \\
\text { Sim } \\
\text { Pre }\end{array}$ & & $\begin{array}{l}\text { At } \\
\text { At }\end{array}$ & & $\begin{array}{l}\text { At } \\
\text { At }\end{array}$ & 20 & $\begin{array}{l}51.41 \pm 20.92 \\
32.14 \pm 9.36\end{array}$ \\
\hline $\begin{array}{l}\text { Gomesin } \\
\text { Sim } \\
\text { Pre }\end{array}$ & 75 & $\begin{array}{l}59.14 \pm 2.46 \\
19.31 \pm 9.64\end{array}$ & 50 & $\begin{array}{l}31.73 \pm 2.46 \\
52.25 \pm 4.27\end{array}$ & 20 & $\begin{array}{l}18.32 \pm 9.16 \\
\mathrm{Nt}\end{array}$ \\
\hline $\begin{array}{l}\text { Clavanin A } \\
\text { Sim } \\
\text { Pre }\end{array}$ & & $\begin{array}{l}\text { At } \\
\text { At }\end{array}$ & 25 & $\begin{array}{l}94.72 \pm 5.59 \\
61.54 \pm 13.60\end{array}$ & 50 & $\begin{array}{l}69.40 \pm 13.13 \\
95.46 \pm 34.42\end{array}$ \\
\hline $\begin{array}{l}\text { Magainin } \\
\text { Sim } \\
\text { Pre }\end{array}$ & 35 & $\begin{array}{l}24.06 \pm 13.19 \\
23.77 \pm 5.70\end{array}$ & 35 & $\begin{array}{l}29.35 \pm 2.74 \\
20.36 \pm 3.88\end{array}$ & 30 & $\begin{array}{l}29.90 \pm 11.18 \\
13.84 \pm 3.18\end{array}$ \\
\hline $\begin{array}{l}\text { HCTF } \\
\text { Sim } \\
\text { Pre }\end{array}$ & 80 & $\begin{array}{l}30.27 \pm 2.03 \\
\mathrm{Nt}\end{array}$ & & $\begin{array}{l}\mathrm{Nt} \\
\mathrm{Nt}\end{array}$ & & $\begin{array}{l}\mathrm{Nt} \\
\mathrm{Nt}\end{array}$ \\
\hline $\begin{array}{l}\text { Penaeidin-3 } \\
\text { Sim } \\
\text { Pre }\end{array}$ & 100 & $\begin{array}{l}85.17 \pm 7.11 \\
34.26 \pm 9.10\end{array}$ & 40 & $\begin{array}{l}28.00 \pm 7.51 \\
32.37 \pm 11.79\end{array}$ & 20 & $\begin{array}{l}12.75 \pm 9.08 \\
56.65 \pm 2.58\end{array}$ \\
\hline $\begin{array}{l}\text { ALF } \\
\text { Sim } \\
\text { Pre }\end{array}$ & 45 & $\begin{array}{l}72.07 \pm 17.02 \\
58.50 \pm 8.20\end{array}$ & 15 & $\begin{array}{l}98.17 \pm 4.24 \\
33.85 \pm 7.50\end{array}$ & 35 & $\begin{array}{l}9.58 \pm 3.39 \\
27.07 \pm 22.51\end{array}$ \\
\hline $\begin{array}{l}\text { Mytilin A } \\
\text { Sim } \\
\text { Pre }\end{array}$ & 40 & $\begin{array}{l}34.28 \pm 7.40 \\
96.11 \pm 4.33\end{array}$ & & $\begin{array}{l}\mathrm{Nt} \\
\mathrm{Nt}\end{array}$ & 80 & $\begin{array}{l}33.12 \pm 2.56 \\
17.64 \pm 5.83\end{array}$ \\
\hline
\end{tabular}

Conc: concentrations are expressed in $\mu \mathrm{M} ; \%$ : results are expressed as mean \pm SDM of three separate experiments; Sim: simultaneous assay; Pre: pretreatment assay; HCTF: hemocyanin C-terminal factor; ALF: antilipolysaccharide factor; At: already tested by other authors (see Murakami et al. 1991 and Yasin et al. 2000); Nt: not tested.

The percentages of protection as well as the $\mathrm{EC}_{50}$ values were calculated as described above. All assays were performed in triplicate.

\section{RESULTS AND DISCUSSION}

All evaluated peptides were cytotoxic, in different degrees, for at least one of the cell lines after the respective period of incubation, which were equivalent to the length of time the monolayers would be exposed to the peptides during the antiviral assays (Table II). The compounds were therefore assayed for antiviral activity at concentrations below or equal to the $\mathrm{CC}_{50}$ values.

Anti-HSV-1 effects - As shown in Table III, PW-2, ALF, Gomesin, and Penaeidin-3 exhibited significant activity against HSV-1 in the simultaneous treatment. Penaeidin-3 inhibited over $85 \%$ of the viral replication at $100 \mu \mathrm{M}$, with an $\mathrm{EC}_{50}$ value of $1.56 \pm 0.18$, resulting in a selectivity index $\left(\mathrm{SI}=\mathrm{CC}_{50} / \mathrm{EC}_{50}\right)$ of 64 (data not shown). Its unique mixed structure among the evaluated peptides (a linear proline-rich N-terminal fragment with a cyclic C-terminal fragment with three disulfide bonds) may have contributed to the detected activity, since another study has already described this feature (Yasin et al. 2000, Yang et al. 2003).

In the pretreatment strategy only ALF and Mytilin A inhibited viral replication notably (Table III). Although ALF exhibited similar percentage of inhibition in both strategies, Mytilin A presented a low percentage of inhibition in the simultaneous assay $(34.28 \pm 7.40)$ and a complete inhibition of viral replication in the pretreatment. Therefore, we speculate that this peptide, with a highly compact cysteine-rich structure, may exert its antiviral activity through a competition with the viral attachment/entry sites for binding to cell surface (van der Strate et al. 2001).

Anti-AdV-5 effects - Even though significant percentage of inhibition were obtained with ALF $(98.17 \pm 4.24)$ and Clavanin A $(94.72 \pm 5.59)$ in the simultaneous treatment, and with Gomesin (52.25 \pm 4.27$)$ and Clavanin A $(61.54 \pm 13.60)$ in the pretreatment, the active concen- 
trations were too close to the $\mathrm{CC}_{50}$ values of these peptides, resulting in low selectivity indices (data not shown). Since most AMPs exert their antiviral activity by interfering with membranes, the activity against non-enveloped viruses is of particular interest, justifying further modifications of peptide structures to increase their selectivity (Yasin et al. 2000, Orsi 2004).

Anti-RV-SA11 effects - The majority of the evaluated peptides presented low percentage of inhibition (Table III), except by clavanin A, which inhibited $69.40 \% \pm$ 13.13 and $95.46 \% \pm 34.42$ of viral replication in the simultaneous and pretreatment assays, respectively. Although a study has described the role of clavanin A glycine residues in its interaction with lipid bilayers (van Kan et al. 2001), the RV-SA11 does not possess a lipid envelope in its structure, thus we speculate that this peptide may exert its antiviral activity through an additional mechanism that interferes in the early steps of viral infection, since a higher percentage of viral replication inhibition was detected in the pre-treatment assay.

Despite the fact that most of the evaluated peptides that presented antiviral activity in this study were only active at concentrations too close to their $\mathrm{CC}_{50}$ values, the results obtained here are promising, and further modifications on the peptide structures may increase selectivity, allowing upcoming investigations about their mode of action.

\section{REFERENCES}

Bachère E, Destoumieux D, Bulet P 2000. Penaeidins, antimicrobial peptides of shrimp: a comparison with other effectors of innate immunity. Aquaculture 191: 71-88.

Bettega JMR, Teixeira H, Bassani VL, Barardi CRM, Simões CMO 2004. Evaluation of the anti-herpetic activity of standardized extracts of Achyrocline satureioides. Phytother Res 18: 819-823.

Bulet P, Stöcklin R, Menin L 2004. Anti-microbial peptides: from invertebrates to vertebrates. Immunol Rev 198: 169-184.

Charlet M, Chernysh S, Philippei H, Hetru C, Hoffmann JA, Bulet $P$ 1996. Isolation of several cysteine-rich antimicrobial peptides from the blood of a mollusc, Mytilus edulis. J Biol Chem 271: 21808-21813.

Chinchar VG, Bryan L, Silphadaung U, Noga E, Wade D, RollinsSmith L 2004. Inactivation of viruses infecting ectothermic animals by amphibian and piscine antimicrobial peptides. Virology 323: 268-275.

da Silva Jr A, Kawazoe U, Freitas FFT, Gatti MS, Dolder H, Schumacher RI, Juliano MA, da Silva MJ, Leite A 2002. Avian anticoccidial activity of a novel membrane-interactive peptide selected from phage display libraries. Mol Biochem Parasitol 120: 53-60.

Destoumieux-Garzon D, Saulnier D, Garnier J, Jouffrey C, Bulet $P$, Bachère E 2001. Crustacean immunity. Antifungal peptides are generated from the $\mathrm{C}$ terminus of shrimp hemocyanin in response to microbial challenge. J Biol Chem 276: 47070-47077.

Lee IH, Zhao C, Cho Y, Harwig SS, Cooper EL, Lehrer RI 1997. Clavanins, alpha-helical antimicrobial peptides from tunicate hemocytes. FEBS Lett 400: 158-162.

Mandard N, Bulet P, Caille A, Daffre S, Vovelle F 2002. The solution structure of gomesin, an antimicrobial cysteine-rich peptide from the spider. Eur J Biochem 269: 1190-1198.

Matanic VCA, Castilla V 2004. Antiviral activity of antimicrobial cationic peptides against Junin virus and herpes simplex virus. Int J Antimicrob Agents 23: 382-389.

Mossmann T 1983. Rapid colorimetric assay of cellular growth and survival: application to proliferation and cytotoxicity assays. J Immunol Methods 65: 55-63.

Murakami T, Niwa M, Tokunaga F, Miyata T, Iwanaga S 1991. Direct virus inactivation of tachyplesin I and its isopeptides from horseshoe crab hemocytes. Chemotherapy 37: 327-334.

Oevermann A, Engels M, Thomas U, Pellegrini A 2003. The antiviral activity of naturally occurring proteins and their peptide fragments after chemical modification. Antiviral Res 59: 23-33.

Orsi N 2004. The antimicrobial activity of lactoferrin: current status and perspectives. Biometals 17: 189-196.

Park Y, Hahm KS 2005. Antimicrobial peptides (AMPs): peptide structure and mode of action. J Biochem Mol Biol 38: 507-516.

Sieuwerts A, Klijn JGM, Peters HA, Foekens JA 1995. The MTT tetrazolium salt assay scrutinized: how to use this assay reliably to measure metabolic activity of cell cultures in vitro for the assessment of growth characteristics, $\mathrm{IC}_{50}$-values and cell survival. Eur J Clin Chem Clin Biochem 33: 813-823.

Somboonwiwat K, Marcos M, Tassanakajon A, Klinbunga S, Aumelas A, Romestand B, Guequen Y, Boze H, Moulin G, Bachère $E$ 2005. Recombinant expression and anti-microbial activity of anti-lipopolysaccharide factor (ALF) from the black tiger shrimp Penaeus monodon. Dev Comp Immunol 29: 841-851.

Sun L, Finegann CM, Kish-Catalone T, Blumenthal R, GarzinoDemo P, La Terra Maggiore GM, Berrone S, Kleinman C, Abdelwahab S, Lu W, Garzino-Demo A 2005. Human betadefensins suppress human immunodeficiency virus infection: potential role in mucosal protection. J Virol 79: 14318-14329.

Takeuchi H, Baba M, Shigeta S 1991. An application of tetrazolium (MTT) colorimetric assay for the screening of anti-herpes simplex virus compounds. J Virol Methods 33: 61-71.

van der Strate BWA, Beljaars L, Molema G, Harmsen MC, Meijer DKF 2001. Antiviral activities of lactoferrin. Antiviral Res 52: 225-239.

van Kan EJM, van der Bent A, Demel RA, de Kruijff B 2001. Membrane activity of the peptide antibiotic clavanin and the importance of its glycine residues. Biochemistry 40: 6398-63405.

Yang Y, Poncet J, Garnier J, Zatylny C, Bachère E, Aumelas A 2003. Solution structure of the recombinant penaeidin-3, a shrimp antimicrobial peptide. J Biol Chem 278: 36859-36867.

Yasin B, Pang M, Turner JS, Cho Y, Dinh NN, Waring AJ, Lehrer RI, Wagar E 2000. Evaluation of the inactivation of infectious herpes simplex virus by host defense peptides. Eur J Clin Microbiol Infect Dis 19: 187-194.

Zasloff M 1987. Magainins, a class of antimicrobial peptides from Xenopus skin: isolation, characterization of two active forms, and partial cDNA sequence of a precursor. Proc Natl Acad Sci USA 84: 5449-5453.

Zasloff M 2002. Antimicrobial peptides of multicellular organisms. Nature 415: 389-395. 